\title{
The Servant Species: Humanity as Priesthood
}

\author{
The Reverend Dr. Andrew Linzey \\ Centre for the Study of Theology \\ University of Essex, England
}

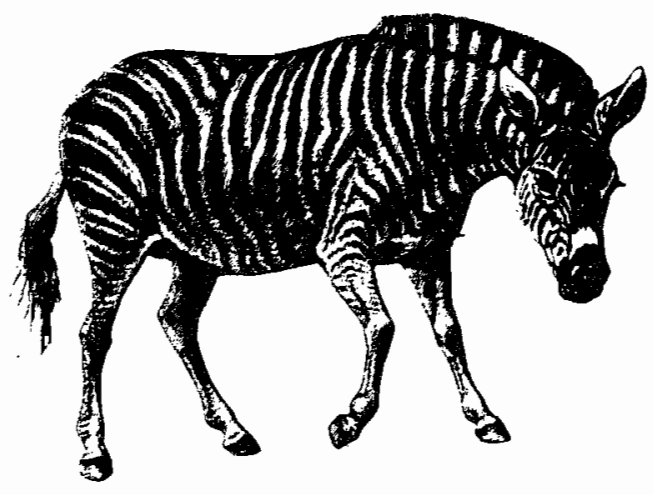

My starting point is a question: In what way, if at all, are human beings unique in creation? In the past, there have been almost too many answers to that question. A whole range of unique and crucial differences has been canvassed: humans alone have rationality, culture, language; humans alone are persons, the possessors of an immortal soul; humans alone are self-conscious and are solely capable of sentient existence. Humans alone are capable of praising God and entering into relationship with the divine. There seems no end to the possibilities of uniqueness which humans can contemplate for themselves when they compare themselves to other species. The notion of the image of God has furthered an extensive uniqueness-searching anthropology which has dominated Christian tradition for centuries, irritating one distinguished Hebrew scholar, James Barr, into denying that the notion of the image refers to anything tangible at all, referring to such attempts as "the blood-out-of-a-stone process." 1

There are at least three reasons why theology should be suspicious of this uniqueness-spotting tendency. The first and most obvious is that a good number of these differences have tumed out to be not so unique

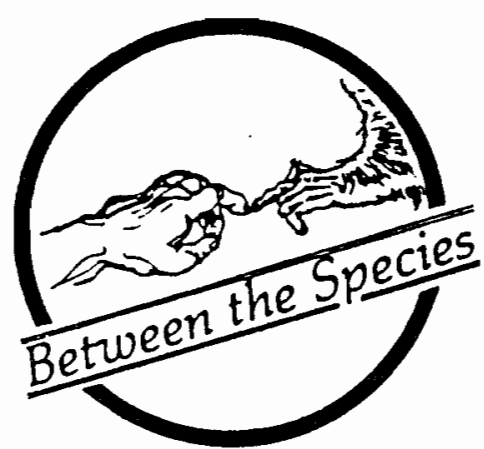

after all. For example, few now share the conviction of Aquinas that only humans in creation are capable of rationality or intelligence in its broadest sense. Even fewer now share the enthusiasm of Descartes for the view that animals are automata, mechanisms utterly devoid of self-consciousness, and therefore incapable of feeling pain. An unmistakable sense of caution in this regard is registered by Robert Runcie, the Archbishop of Canterbury, in a recent lecture. "[B]oth in theory and practice the boundaries of the human family are becoming unclear," he argues. Behind practical dilemmas,

there lies the theoretical difficulty of defining what it is that decisively distinguishes the human from the non-human - a difficulty that increases as, for instance, naturalists detect in non-human creatures subtleties of behaviour and complexities of communication which, until recently, would have been thought unique and exclusive of humans. ${ }^{2}$

Then there may be a question as to why humans find it necessary to place themselves in a distinct category from animals. One of the conclusions of Desmond Morris' popular book, The Naked Ape, which aroused most Christian commentators to complain, was his

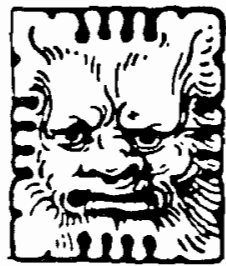

- Andrew Linzey 1989 RELIGION 
insistence that our desire to be placed above the animals was itself a sign of insecurity. "Unfortunately, because we are so powerful and so successful when compared with other animals, we find the contemplation of our humble origins somehow offensive, so that I do not expect to be thanked for what I have done," he wrote.

Our climb to the top has been a get-rich-quick story, and, like all nouveaux riches, we are very sensitive about our background. We are also in constant danger of betraying it. ${ }^{3}$

To these suspicions needs to be added a third, namely that the distinctions we have drawn have been frequently and transparently self-serving, even selfish. For example, it seems to be altogether too convenient for Aristotle to take simply one example - to suppose that since "nature makes nothing without some end in view," it must follow that nature has made all animals "for the sake of man." It has been so easy to turn this appeal to the purpose of nature, and in subsequent Christian centuries to "divine purpose," into a justification for doing what we like to animals that we have come to suspect the opposite is the true sequence. Aquinas, following Aristotle, appeals both to the order of nature and also to divine providence to assure us that "it is not wrong for man to make use of them, either by killing or in any other way whatever."5 The difference-finding tendency in Western tradition has undoubtedly served to minimize the moral standing of nonhuman creatures and to enable us to exploit them with a clear conscience. One cannot be but bemused by the reference in the marriage service of the Book of Common Praver to "brute beasts that hath no understanding," since some, perhaps many, higher mammals seem to know more about monogamous relationships than at least some members of homo sapiens. ${ }^{6}$ In short: much of our uniquenessspotting within the Christian tradition has been linked directly or indirectly to the fostering of a low view of animality, the traces of which are still found in our language about "brutes", "beasts," and "bestial"; even the word "animal" has become a libel - and not just on human beings.

In a little but significant book of theological fantasy, entitled Travels in Oudamovia, John Austin Baker describes the traveller's reaction to Oudamovian life and worship, which was characterized by a friendly nonexploitive relationship with animals:
The truth they strove to bring home was that the world God has given to his creatures, the one world which they have to share, is in fact a different world to each one of them, but that the world each creature knows is equally true. We human beings, superior as we are, ought to be very humble because other creatures have other truths which we can only dimly grasp, worlds we can never fully enter.

He concludes with this question:

And if this is so with regard to an ox or an ant, not to say a tree or a stone, how can we hope to comprehend the God who comprehends them all, to whom all worlds and truths are fully known because he made them? ${ }^{7}$

This interesting question leads me again to my starting point. Let me now frame the question in this way. Is it possible to have a theological understanding of humans as unique which avoids the suspicions and dangers of self-service, insecurity, and moral denigration of what is different - not to mention a view which might broadly be reconcilable with empirical evidence?

\section{II}

I begin this second section by laying some stress on this word "theological." For it seems that many of the previous claims for human uniqueness have been essentially naturalistic rather than theological. I mean by this that they have appealed to certain abilities, qualities, or capacities, such as rationality, or power, or selfconsciousness, which are taken as determinative of what is uniquely human. Such attempts I want to suggest are not theological in the strict sense of being things which are grounded in the nature of God itself. Despite the traveller in Oudamovia's not wholly unjust complaint that "our understanding of God is even less adequate than our understanding of the life of our cat"8, it is here that there may be a way forward.

If we take the gospel narratives seriously, it may be that there is at least one thing we can know. It seems appropriate to describe this truth in the form of a story. It is from Helen Waddell's Peter Abelard. Peter, you may recall, had been made to suffer a terrible injustice from people who had taken the law into their own hands. In 
this passage, Peter is walking close to a wood with his friend, Thibault.

'My God,' said Thibault, 'what's that?'

From somewhere near them in the woods a cry had arisen, a thin cry, of such intolerable anguish that Abelard tumed dizzy on his feet, and caught at the wall.

'It's a child's voice,' he said. 'O God, are they at a child?'

'A rabbit,' said Thibault. He listened. 'There's nothing worrying it. It'll be in a trap. Hugh told me he was putting them down. Christ!' The scream came yet again.

Abelard was beside him, and the two plunged down by the bank... 'O God', [Abelard] was muttering. 'Let it die. Let it die quickly.'

But the cry came yet again. On the right, this time. He plunged through the thicket of hombeam.

'Watch out,' said Thibault, thrusting past him. 'The trap might take the hand off you.'

The rabbit stopped shrieking when they stooped over, either from exhaustion, or in some last extremity of fear. Thibault held the teeth of the trap apart, and Abelard gathered up the little creature in his hands. It lay for a moment breathing quickly, then in some blind recognition of the kindness that it met at the last, the small head thrust and nestled against his arm, and it died.

It was the last confiding thrust that broke Abelard's heart. He looked down at the little draggled body, his mouth shaking. 'Thibault,' he said, 'do you think there is a God at all? Whatever has come to me, I earned it. But what did this one do?'

Thibault nodded.

'I know,' he said. 'Only - I think God is in it too.'

Abelard looked up sharply.

'In it? Do you mean that it makes Him suffer, the way it does us?'

Again Thibault nodded.

'Then why doesn't He stop it?'

'I don't know,' said Thibault. 'Unless unless it's like the Prodigal Son. I suppose the father could have kept him at home against his will. But what would have been the use? All this,' he stroked the limp body, 'is because of us. But all the time God suffers. More than we do.'

Abelard looked at him, perplexed.

'Thibault, when did you think of all this?'

Thibault's face stiffened. 'It was that night,' he said, his voice strangled. 'The things we did to poor Guibert. He -' Thibault stopped. 'I could not sleep for nights and nights. And then I saw that God suffered too. And I thought that I would like to be a priest.'

'Thibault, do you mean Calvary?'

Thibault shook his head. 'That was only a piece of it - the piece that we saw - in time. Like that.' He pointed to a fallen tree beside him, sawn through the middle. 'That dark ring there, it goes up and down the whole length of the tree. But you only see where it is cut across. That is what Christ's life was; the bit of God that we saw. And we think God is like that, because Christ was like that, kind and forgiving sins and healing people. We think God is like that for ever, because it happened once with Christ. But not the pain. Not the agony at the last. We think that stopped.'

Abelard looked at him, the blunt nose and the wide mouth, the honest troubled eyes. He could have knelt before him. 'Then, Thibault,' he said slowly, 'you think that all this,' he looked down at the quiet little body in his arms, 'all the pain of the world was Christ's cross?'

'God's cross,' said Thibault. 'And it goes on.'

'The Patripassian heresy,' muttered Abelard mechanically. 'But, O God, if it were true. Thibault, it must be. At least, there is something at the back of it that is true. And if we could find it - it would bring back the whole world.'9

The point then so ably narrated by Waddell is this: God suffers. I shall not be concemed here with the precise theories about how God may be thought to suffer. Notwithstanding Abelard's "mechanical" description of this view as "the Patripassian heresy," it seems to me that there are a variety of ways in which we can understand 
God as suffering presence in the world that do not lose sight of divine omnipotence or indeed divine transcendence. Even so gospel-centred a scholar as Tom Torrance can be so nervous about an outright declaration of divine passibility that he resolves the problem by simply affirming the contradiction: God "redeems our passability in his impassability."10 But I want to leave that debate to one side, and suggest that the insight derived from God's self-definition in Jesus Christ leads inescapably to the view that God really and truly enters into suffering. This seems to me to be required by a fully incarnational theology in which God actually does what is claimed - namely enter into the awfulness of the human condition.

But like Thibault in the story, I want to go further. If it is true that God is the Creator and sustainer of the whole world of life, then it is inconceivable that God is not also a co-sufferer in the world of nonhuman creatures as well. Years of Christian tradition has obscured this basic implication of the gospel narrative for at least two reasons. The first is because the scholastic tradition in particular has denied to animals any moral standing, so that even if they did suffer, such suffering was not regarded as morally significant. The second, and more obvious reason, is that later Christian tradition, especially manifest in Cartesianism, simply denied that animals could feel pain at all. Even in this century notable theologians, such as Charles Raven, argued not just that animals did not suffer like humans but rather doubted that they suffered at all. ${ }^{11}$

And yet the idea that God is affected by the suffering of all creatures has not been lost on generations of saints and poets. "Here I saw the great unity between Christ and us," writes Julian of Norwich, "for when he was in pain, all creatures able to suffer pain suffered with him." 12 It is written of Margery Kempe that "[w]hen she saw a crucifix, or if she saw a man had a wound, or a beast, or if a man beat a child before her, or smote a horse or another beast with a whip, she thought she saw Our Lord beaten and wounded."13 In this Julian and Kempe may have something in common with Cardinal Newman: "Think of your feelings at cruelty practiced upon brute animals,' writes Newman, "and you will gain the sort of feeling which the history of Christ's Cross and Passion ought to excite within you."14

Perhaps the best known expression of this idea in poetry is found in Joseph Plunkett's I See His Blood Unon the Rose:
I see His blood upon the rose

And in the stars the glory of His eyes,

His body gleams amid etemal snows,

His tears fall from the skies.

I see His face in every flower;

The thunder and the singing of the birds

Are but His voice - and carven by His power

Rocks are His written words.

All pathways by His feet are worn, His strong heart stirs the ever-beating sea, His crown is twinned with every thorn,

His cross is every tree. ${ }^{15}$

More satisfactory I think is Edith Sitwell's Still Falls the Rain in which she pictures Christ's redeeming blood - like rain - continuing to fall on the wounds of the suffering world.

He bears in his Heart all wounds, -- those of the light that died,

The last faint spark

In the self-murdered heart, the wounds of the sad uncomprehending dark,

The wounds of the baited bear, -

The blind and weeping bear whom the keepers beat

On his helpless flesh. . the tears of the hunted hare.

Still falls in Rain -

Then - O I leape up to my God: who pulles me doune -

See, see where Christ's blood streames in the firmament:

It flows from the Brow we nailed upon the tree

Deep to the dying, to the thirsting heart

That holds the fires of the world, dark smirched with pain

At Caesar's laurel crown.

Then sounds the voice of one who like the heart of man

Was once a child who among beasts was lain -

'Still do I love, still shed my innocent light, my Blood, for thee.' 16 
This imaginative picture of Christ suffering all pain and violence in the universe that God has made conveys - it seems to me - a truth which has simply eluded the formal theorists and dogmaticians of the Christian tradition. Only very faintly, if at all, has the church allowed this truth to be expressed in its liturgy. For example, in the Byzantine rite for Holy Saturday it is held that "[t]he whole creation has altered by thy Passion; for all things suffered with thee, knowing $\mathrm{O}$ Lord, that thou holdest all things in unity." 17 But this splendid example, I fear, is one of the comparatively few exceptions to an otherwise almost wholly monolithic anthropocentrism of East and West.

It seems to me that the recognition that suffering exists in the nonhuman world requires us to grapple with the problem of redemption for these spheres as well. If it is believed, in fidelity to the gospel story, that God truly enters into creaturely suffering, then there can be no good reason for excluding God's suffering presence from the realm of the nonhuman creation as well. Indeed, quite the reverse. For the issue is not how much suffering or to what degree any being suffers, but that it suffers at all which is the underlying fact to be wrestled with. If as Bonhoeffer once remarked, "only a suffering God can help," it must follow that where there is suffering - no matter whatever the kind and to what degree - God suffers too.

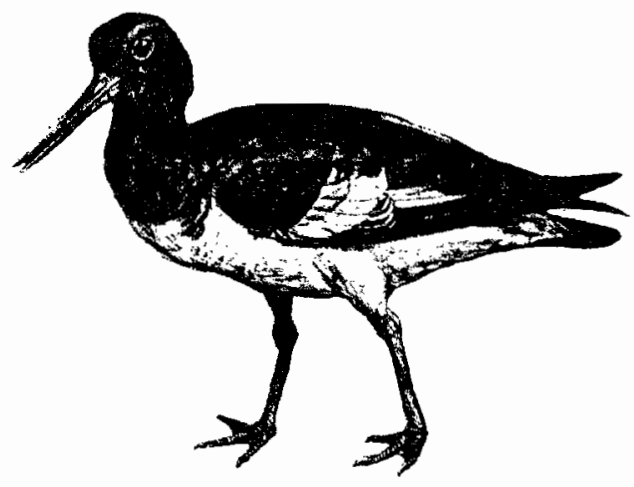

\section{III}

I now turn to my third section. You may recall Thibault's reaction to the question of suffering. Not only did he hold that God suffered in all suffering creatures, but also, reflecting upon that suffering in both humans and animals, he had decided to become a priest. "And then I saw that God suffered too," he said. "And I thought I would like to be a priest." At first sight this might appear to be a rather unusual reaction. It has to be said that many prevailing notions of priesthood would find the relationship, if any, hard to fathom. Yet it seems to me that "Thibaultian theology" (if I may describe it so) is altogether coherent. For if Christian priesthood derives its authority from Christ, as the focus of God's own self-definition, then it should also follow that priesthood is an extension of the suffering, and therefore also redeeming, activity of God in our world.

The one point I want to make here is this: The wider definition of God's presence, and therefore also his redeeming power, necessitates in turn a wider definition of priesthood. I am by no means the first person to think of priesthood in wider, we might say ecological, terms. Alexander Pope in his "Essay on Man" describes the divine commission to have dominion and to look after the world in terms of Christian priesthood:

The state of Nature was the reign of God. . .

Man walked with beast, joint tenant of the shade;

The same his table and the same his bed;

No murder cloth'd him, and no murder fed...

Unbrib'd, unbloody, stood the blameless priest:

Heaven's attribute was Universal Care,

And Man's prerogative to rule, but spare. ${ }^{18}$

One of the first to use the phrase "the World's High Priest" was Archbishop Leighton in the seventeenth century. He spoke of the priest in the Psalmist's sense of offering the praises of all creatures to their God:

All things indeed declare and speak His glory: the Heavens send it forth, and the Earth and Sea resound and echo it back. But His reasonable creatures hath $\mathrm{He}$ peculiarly framed both to take notice of His glory in all the rest, and to return it from and for all the rest in a more express and lively way. 
And in this lower world it is Man alone that is made capable of observing the Glory of God, and of offering Him praises. $\mathrm{He}$ expresses it well who calls man "the World's High Priest."19

Such thoughts are similar to those expressed by Coleridge, who in his poem "To Nature" anticipates some of the lyricism, if not the actual lyrics, of Teilhard de Chardin's "Mass Upon the Altar of the World."20

It may indeed be phantasy when I

Essay to draw from all created things

Deep, heartfelt, inward joy that closely clings:

And trace in leaves and flowers that round me lie

Lessons of love and earnest piety.

So let it be; and if the wide world rings

In mock of this belief, to me it brings

Nor fear, nor grief, nor vain perplexity.

So will I build my altar in the fields,

And the blue sky my fretted dome shall be,

And the sweet fragrance that the wild

flower yields

Shall be the incense I will yield to Thee,

Thee only God! and Thou shalt not despise

Even me, the priest of this poor sacrifice. ${ }^{21}$

This notion of sacrifice is taken up by George Herbert in perhaps the best-known lines of all on this theme:

Man is the world's High Priest: he doth present

The sacrifice for all; while they below

Unto the service mutter an assent,

Such as springs use that fall, and winds that blow.22

Already we see the two familiar themes of Christian priesthood expressing themselves: the priest is the one who "present(s)" or represents, and also the one who offers up "the sacrifice for all." But what does it mean to exercise a representative and sacrificial priesthood for the whole created order? Who is representing whom, and who is sacrificing what?

First, I want to suggest that the priest is the icon of Christ. The priest is to present and represent the love of God focused in Jesus Christ. "Have this mind among yourselves, which you have in Christ Jesus, who, though he was in the form of God, did not count equality with God a thing to be grasped, but emptied himself taking the form of a servant."23 It is this conception of the omnipotence of God expressed in service which constitutes the decisive paradigm of how we should exercise our lordship or dominion over the nonhuman creation. If it is true that the power of God is most authentically expressed in the form of suffering service, then we have to ask ourselves radical questions about how we are to understand our own lordship or dominion over nature in general and animals in particular. If we are to have among us the mind of the one whose power is expressed in humility, in condescension, in reaching out to the least of all, has not our own relationship to the suffering nonhuman got to undergo a fundamental re-examination? Almost alone among contemporary theologians, Torrance articulates the connection between the suffering world and the human world of priestly redemption. Torrance holds to a high view of humanity:

From the perspective of theology, man is clearly made the focus point in the interrelations between God and the universe. He is given a special place within creation with a ruling and a priestly function to perform toward the rest of created reality. All lines of rationality and order, of purpose and fulfillment in the creation converge on him as man of God and man of science and depend upon his destiny.

But unlike others, Torrance does not stop here with the familiar theme of theological self-congratulation. He couples his high view of humanity with a strong view of human responsibility:

this priestly role of man must take on a redemptive form - that is how we should view man's relationship to nature. It is his task to save the natural order through remedial and integrative activity, bringing back order where there is disorder and restoring peace where there is disharmony. ${ }^{24}$

In short: the representative function of priesthood is the presentation and actualization of God's suffering service in the world. 
Second, I want to suggest that Christ-like priesthood is necessarily sacrificial. But what or whom is to be sacrificed? Archbishop Leighton, and others before and after him, have understood this sacrificial work in terms of the offering of thanksgiving. "[I]n this lower world," writes Leighton, "it is Man alone that is made capable of observing the glory of God, and of offering him praises." John Zizioulas, in a recent lecture, develops the point further when he describes the priest as the one who "refers the world back to [its] Creator."25 Now, I do not want to deny that the offering of thanksgiving, even on behalf of other creatures, is an important aspect of priesthood - though I would have to say that it is not clear to me that other creatures do not praise and commune with their Creator in their own way. But leaving that question aside, it seems insufficient to allow thanksgiving as the sole or major definition of what the priest has to offer.

Neither do I think that the sacrificial aspect of priesthood is adequately or properly characterized in terms of sacrificing other forms of life such as animals. "The killing of animals," writes Karl Barth, "when performed with the permission of God and by His command, is a priestly act of eschatological character."26 But whatever may be the meaning and historical significance of the forms of animal sacrifice in the Old Testament - and about this I recognize that there is no little discussion ${ }^{2 n}$ - it seems to me very difficult indeed to reconcile the spirit of Christ-like sacrifice with animal sacrifice, and for two reasons. The first is that Christian sacrifice is primarily to do with the offering of life and especially love - rather than blood (although Good Friday is real enough), and second, the intemal logic of Christ's sacrifice is the sacrifice of the higher for the lower and not the reverse. It does not seem irrelevant to point out here that Jesus did not sacrifice animals and, arguably, by his cleansing of the Temple indicates more than an ambivalent relationship to this practice. ${ }^{28}$

But the central point I want to make here is this: The priestly work of sacrifice is best characterized by the offering of self-costly love as exemplified by Christ himself. To make this point clearer, I want to draw on another New Testament image, this time not that of Christ as the suffering servant in Phillippians but, rather, the image of the world in a state of child-birth in Romans. The creation groans in travail because it is subject not by its own will to "bondage and decay."
"For the creation waits with eager longing for the revealing of the sons of God," writes St. Paul, "because the creation itself will be set free...and obtain the glorious liberty of the children of God." 29 What does it mean for humans to exercise a priestly role of redemption? Quite simply: it concerns the releasing of creation from futility, from suffering and pain and worthlessness. This, I want to suggest, is the divine work of redemption to which humans are called by the power of the Spirit. It is the liberation of creation itself from decay and suffering perhaps in some ways the most fundamental liberation of all. Such a perspective challenges at root the notion that human responsibility in the world extends only to serving and protecting our own species. Keith Ward's paraphrase of Genesis 1, namely that "man" is made a "god" in creation and that creatures "should serve him" needs rethinking. ${ }^{30}$ I suggest it should be that humans given lordship or God-like power should serve creation. To reiterate: The inner logic of Christ's lordship is the sacrifice of the higher for the lower, not the reverse. If the humility of God is costly and essential, why should ours be less so?

Strangely enough it is Nietzsche who in a most uncharacteristic piece of writing seems to point in my direction. "The deeper minds of all ages have had pity for animals," he writes, "because they suffer from life and have not the power to turn the sting of their suffering against themselves, and understand their being metaphysically." ${ }^{1}$ According to Nietzsche, nature needs the philosopher and the artist "to strive thereby for the completion of nature." But nature, according to Nietzsche, needs - not only the artist and the philosopher - but also the saint:

In him the ego is melted away, and the suffering of his life is, practically, no longer felt as individual, but as the spring of the deepest sympathy and intimacy with all living creatures...the attainment, at length, of the high state of man after which all nature is striving, that she may be delivered from herself. ${ }^{32}$

And it is concretely in the lives of many saints that we see prefigured this vision of the higher state of nature to which Nietzsche refers. Of the many examples one could give I choose simply one example from St. Isaac the Syrian: "What is a charitable heart?" he asks, and replies as follows: 
It is a heart which is burning with love for the whole creation, for men, for the birds, for the beasts, for the demons - for all creatures. $\mathrm{He}$ who has such a heart cannot see or call to mind a creature without his eyes being filled with tears by reason of the immense compassion which seizes his heart; a heart which is softened and can no longer bear to see or leam from others of any suffering, even the smallest pain being inflicted upon a creature. That is why such a man never ceases to pray for the animals.... He will pray even for the reptiles, moved by the infinite pity which reigns in the hearts of those who are becoming united with God. ${ }^{33}$

This last sentence goes some way to encapsulate the point I want to stress: It is not just that sensitivity to suffering is, or should be, a characteristic of priesthood or saintliness, though I think it should be. It is rather that sensitivity to suffering (and with it compassion, empathy, mercy, loving forgiveness) are the hallmarks of priesthood itself. Only when we can say that we too have entered - however fleetingly - into the suffering of Christ in the suffering of all creatures can we claim to have entered into the priestly nature of our humanity. More even than that, for the goal of our priestly humanity as I see it is not, as St. Isaac reminds us, simply passive. We are to be active in prayer and deed to ensure that we reflect not just Christ-like feeling for the suffering of the world but also Christ-like healing. We are not called to be mere spectators of the world of suffering but active co-participants with God the Holy Spirit in its redemption.

\section{IV}

I turn now to my fourth section. My starting point was the question: In what way, if any, are humans unique in the creation God has made? The argument I have sketched has been as follows: We need three shifts in our thinking. First, away from the idea that if God suffers at all, this suffering takes place solely within the human species, to the view that God suffers in all suffering creatures. Second, a shift away from a narrow conception of priesthood as largely or exclusively concerned with God and humanity - to the view that priesthood is a participation in God's redeeming presence in the world. And third, a shift away from the idea that the characteristics of priesthood - namely representation and sacrifice - can be detailed in a wholly human-centred way without involving the exercise of Christ-like power and service to the whole of creation.

The answer I want to give then to my opening question is this: The uniqueness of humanity consists in its ability to become the servant species, to exercise its full humanity as co-participants and co-workers with God in the redemption of the world. This view challenges the traditional notions that the world was made simply for human use or pleasure, that its purpose consists in serving the human species, or that the world exists largely in an instrumentalist relationship to human beings. Only the most tenacious holding on to the passibility of God may be sufficient to redeem us from our own profoundly arrogant humanistic conceptions of our place in the universe.

It is important, however, to spell out the implications of the doctrine of priestly service which I have espoused. The first is that humanity can have no right to regard sentient creatures especially as simply means to their ends. Animals are not simply here for our use, and to use animals at all incurs a very great responsibility. I agree with the principle commended by Stephen R. L. Clark that it is wrong to be the cause of avoidable injury. But I would, perhaps, go further. To make animals suffer for human purposes is not just morally wrong, it is an act of the gravest faithlessness. Humphry Primatt, who wrote the most impressive theological treatise on animals, got it right when he wrote that:

We may pretend to what religion we please; but cruelty is atheism. We may make our boast of Christianity, but cruelty is infidelity. We may trust to our orthodoxy, but cruelty is the worst of heresies. ${ }^{34}$

That we now as a matter of course use sentient beings in ways that cause them harm and suffering as laboratory tools, as units of production in farming, as objects of sport and entertainment, is a sign that we have lost not just a sense of our priestly humanity but a sufficient conception of the generosity of God revealed in Jesus Christ. All this is not to deny that we - indeed all nature - is caught up in the structures of disorder of which Torrance speaks. ${ }^{35}$ Neither is it to deny — in my favourite 
line from Albert Schweitzer - that a clean conscience is a figment of the imagination or as he actually puts it "an invention of the devil." ${ }^{36}$ Neither is it to suppose that we can easily turn to live in some Edenite harmony with other creatures. I accept that we are compromised and that we have difficult choices to make.

Nevertheless, I want to suggest that it is here we may sense the possibility of living other than we do, that we should reflect upon the fact that Christian priesthood is sacrificial, costly priesthood. It cannot be sufficient merely to have a negative vision of what we should do to prevent suffering in the world. We need positive vision of how we can take upon ourselves the suffering of the world and transform it by the power of the Holy Spirit. We need to experiment in ways of liberation rather than always assuming that human interest, narrowly conceived, always comes first. To give but one controversial example: It may be that the truly Christian view of the morality of experimentation begins not by asking how much suffering we can legitimately inflict upon animals but rather should we not elect to bear for ourselves whatever ills may flow from not experimenting upon animals rather than using our power to exploit the weak in our own favour. All this has an urgency which in previous generations we failed to appreciate. For our ruthless, un-gentle treatment of the natural world has ushered in a cognizance of certain limits to exploitation. Extinct species, like dead nature itself, can no longer be exploited. It seems to me that Christians have an opportunity in the present circumstances to show what it means to live as though we believe in a generous loving God by living that generosity towards nonhuman creatures.

I now turn to my fifth, and final, section and briefly consider four objections to my argument.

The first queries my whole train of argument by suggesting that I have simply overlooked the powerful "humans come first" tradition within Christianity. According to the Linzey view, it is claimed, we shall end up being more concerned about suffering hens than suffering humans.

I agree with this objection if it means that the suffering of humans - as well as the suffering of nonhumans - should be the subject of the serving and sacrificial priesthood. Nothing in my argument should weaken concern for the healing of suffering humanity. Nevertheless, it is no longer clear to me that we can make an absolute distinction between one kind of suffering and another, either that of a member of another class, race, sex or - I would add - species. Neither is it clear to me that we can in each and every situation claim that human suffering is more important than any other kind of suffering. Indeed, I want to suggest that the attempt to place human well-being in a special and absolute category of its own is one of the reasons why other earthly creatures - indeed, the earth itself remains in a desperate state of travail, a travail so great that its destruction - in part, if not as a whole - seems inevitable. In other words, exclusive moral preoccupation with our own species is part of the problem itself rather than its solution. We should face the fact that years of Christian anthropocentricity (of a bad sort) has helped lead us to the environmental crisis we now encounter. In short, we have to redress the balance and appreciate that humans are not just linked to nature, we are part of nature.

\section{GOROLLA}

\author{
Behind these eyes \\ lies the dawn of time. \\ You make me a monster \\ or a joke. \\ Lock me up so you can stare and laugh. \\ I look back with great sadness \\ for I know your past \\ and I see your destiny. \\ I do not hate you. \\ I am gentle; I am loyal. \\ I have strength \\ beyond this giant's body. \\ I am strong in spirit. \\ My solemn gaze reveals the truth. \\ When you murder me \\ you are killing you. \\ When you imprison my soul \\ you destroy your future.
}

Kathleen Malley 
The second objection is that I have effectively reduced theology to ethics by simply redefining the essential characteristics of priesthood in ethical terms.

Some forms of this objection have my sympathy. John Zizioulas has recently stressed the limitations of a response to the ecological crisis which simply places all its hopes in ethics. "Whether enforced by State legislation or taught or instructed by Churches, academic institutions, etc., it is ethics that seems to contain the hopes of humankind in the present situation," he writes. And yet (he reminds us) "ethics, whether enforced or free, presupposes other more existential motivations in order to function. ${ }^{\text {"37 }}$ It is difficult to deny that Zizioulas is right here. The appeal to ethics, by itself, is insufficient. Yet it is also very understandable. For centuries Christians have kept our relations with the nonhuman out of the ethical sphere, and so it is perhaps not altogether surprising that their inclusion is now seen as a priority.

However, I am not one of those who think that salvation lies in ethics alone. Spiritually unenlightened humanity - especially one that is over-confident of its own humanism - can be a cause of moral darkness. The approach I have outlined is far from naive ethicism. But it may be construed as an attack upon what we have had a surplus of in the Christian tradition, namely non-ethical or anti-ethical theology. I suggest that we need a way of combining the two - theology and ethics - in a much clearer way than heretofore. Moral theology is a more acceptable term; ascetical or mystical theology even better.

But, at a deeper level, what this objection signifies is a divorce between divine activity and human response which is starkly perilous at the present time. The theological challenge is how we can understand the divine work of passibility and redemption already operative within creation through the work of the Holy Spirit. When we have such a conception we shall best be able to fully appreciate the necessity of human response to, indeed, participation in, that work itself.

The third objection takes us back to my initial thesis concerning the passibility of God. How can God suffer etemally and also at the same time offer us liberation from suffering which is the central hope of the Gospel? In short: If God suffers in creation, how can God also redeem us from that suffering?

Again, I have no little sympathy for this objection, which I once held and defended myself. But the weakness of the argument - it now seems to me - is in its view that God cannot both suffer and redeem that suffering at one and the same time. The best, perhaps the only, model we can have is that of the incarnation itself. For if it is possible for God in Christ to enter into the suffering of the world, and yet transform that suffering into joy, why should this capacity be limited in time and space to one event only? I posit that Thibault was right: What is seen in Christ is one instance of the perpetual transformation of suffering happening throughout time.

The fourth objection holds - perhaps on a lighter note - that if we take the view that the higher should have a greater concern for the lower, we shall end up having as much - if not more - concern for asparagus or cabbage or carrots than for human beings.

I do not think so. For the stress in my argument has been on suffering creation. Despite popular notions of talking plants and sentient vegetables, there is actually no evidence that such creatures experience pain. Though, of course, there may be some areas of difficulty and doubt, I can see no good reason why these should prevent us from behaving in a priestly manner to those beings whose capacity for suffering is beyond reasonable doubt. That we may, however, discover sensitivity and sentience outside the human species - in what are to us unlikely place - only reinforces the fact that God has created an amazingly sensitive and delicate world and that wherever we go we should tread gently.

It is important, however, that my argument from suffering should be understood. I do not deny that there are other important characteristics, apart from sentiency, which should be valued or conserved. My stress here is that the special capacity for suffering which we share with so many nonhuman creatures is theologically significant if we subscribe to the doctrine of a suffering, passible God. God may be injured or harmed in creation in a variety of ways - at least conceivably - but none more directly than through the infliction of suffering.

In conclusion, you may recall Abelard's reaction to Thibault's doctrine of divine passibility. "The Patripassian heresy," he muttered "mechanically." "But, $O$ God, if it were true. . . It must be. At least, there is something at the back of it that is true." Then Abelard went on: "And if we could find it - it would bring back the whole world." At first sight it might seem an amazingly presumptious claim that the recovery of the insight of divine passibility could lead to a recovery of the whole world. And yet is it purely coincidental that its contrary view, namely the doctrine of divine impassibility, has triumphed and flourished in Christian 
centuries in which theology about the world - and especially our responsibility for it - - seems to have almost entirely evaporated? It may be that here, as elsewhere, our doctrine of God has been much more significant for the salvation of the world than we might have thought possible. Abelard, I feel sure, would have approved of the mystical theology contained in these moving lines from Schweitzer's autobiography: "I could not but feel with a sympathy full of regret all the pain that I saw around me, not only that of men, but that of the whole creation. From this community of suffering I have never tried to withdraw myself. It seemed to me a matter of course that we should all take our share of the burden of suffering which lies upon the world."38

\section{NOTES}

1. James Barr, "The Image of God in the Book of Genesis - A Study in Terminology," Bulletin of the John Rylands Library, 51, 1, (Autumn 1968) pp. 12/13. Barr appears to reject absolutely any "referential meaning" of the phrase "image of God." He writes that there is "no reason to believe that this writer $(P)$ has in his mind any definite idea about the content or the location of the image of God (ibid)." Such a view should not obscure, however, the possibility of developing an understanding of the "image" in a way that links it with the further notion of "dominion", and which may enhance the view of the priestly role of humanity which I have advocated here.

2. Robert Runcie, in "Theology, the University and the Modern World" in Paul A. B. Clarke and Andrew Linzey (eds.), Theology the University and the Modern World (London: Lester Crook Academic Publishing, 1988), pp. 19/20.

3. Desmond Morris, The Naked Ape (London: Corgi Books, 1969), p. 210.

4. Aristotle, The Politics, ET by T. A. Sinclair (Harmondsworth: Penguin Books, 1985), I, viii, p. 79.

5. Aquinas, Summa Contra Gentiles, ET by the English Dominican Fathers (Benzinger Brothers, 1928), Third Book. Part II, Chp. CXII. Extract in Tom Regan and Peter Singer (eds.), Animal Rights and Human Obligations (New Jersey: Prentice-Hall, 1976), pp. 56-9.

6. See Andrew Linzey, Christianity and the Rights of Animals (London: SPCK, 1987), p. 18.

7. John Austin Baker, Travels in Oudamovia (London: Faith Press, 1976), pp. 53/4.
8. Baker, ibid, p. 54.

9. Helen Waddell, Peter Abelard (London: Granada Publishing, 1972), pp. 194/6

10. Thomas Torrance, The Trinitarian Faith (Edinburgh: T. \& T. Clark, 1988), p. $185 \mathrm{f}$.

11. Charles Raven, The Creator Spirit (London, 1927) p. 120; cited and discussed in A. Richard Kingston "Theodicy and Animal Welfare" in Andrew Linzey and Tom Regan (eds.), Animals and Christianity: $\underline{A}$ Book of Readings (London: SPCK and New York: Crossroads, 1989), p. 77.

12. Julian of Norwich, Showings, ET and introduction by Edmund Collage and James Walsh (New York: Paulist Press, 1978), pp. 130/1.

13. Margery Kempe, in Diary, cited in Ambrose Agius, God's Animals (London: Catholic Study Circle for Animal Welfare, 1970), p. 46.

14. Newman, in Maisie Ward, Young Mr. Newman, p. 350, and cited in Agius, ibid, p. 46.

15. Joseph Plunkett, "I See His Blood Upon the Rose" in Andrew Linzey and Tom Regan (eds.), The Song of Creation: An Anthology of Poems in Celebration of Animals (London: Marshall Pickering, 1988), p. 132.

16. Edith Sitwell, "Still Falls in Rain" in Linzey and Regan, Song of Creation, ibid, p. 132.

17. The Byzantine Rite, verse from the Mattins of Holy Saturday in The Lenten Triodion, ET by Mother Mary and Bishop Kallistos, (London: Faber and Faber, 1978), cited and discussed in A. M. Allchin, The Dynamic of Tradition (London: Darton, Longman and Todd, 1981) and anthologised in Andrew Linzey and Tom Regan (eds.), Compassion for Animals: Prayers and Readings (London: SPCK, 1988), p. 86.

18. Alexander Pope, "Essay on Man," extract in Linzey and Regan, Song of Creation, ibid, p. 33.

19. Archbishop Leighton, cited and discussed in Michael Patemoster, Man:The World's High Priest (Oxford: SLG Press, 1976), p. 7 f. I am grateful to Paternoster for the inspiration to write this paper.

20. Cf. "It was during this expedition, in the stillness of the vast solitude of the Ordos desert, that one Easter Sunday he finished the mystical and philosophical poem, Mass upon the altar of the World. Alone before God, he prays with lyrical 
fervour: "Christ of glory, hidden power stirring in the heart of matter, glowing centre in which the unnumbered strands of the manifold are knit together; strength inexorable as the world and warm as life; you whose brow is of snow, whose eyes are of fire, whose feet are more dazzling than gold poured from the furnace; you whose hands hold captive the stars; you, the first and last, the living, the dead, the reborn; you, who gather up in your superabundant oneness every delight, every taste, every energy, every phase of existence, to you my being cries out with a longing as vast as the universe: for you indeed are my Lord and my God.'" Pierre Leroy, "Teilhard de Chardin; The Man" in Teilhard de Chardin, Le Milieu Divin, edited by Bernard Wall (London: Fontana Books, 1964), p. 26. See also Teilhard de Chardin, Hymn of the Universe, ET by N.M. Wildiers (London: Fontana Books, 1970).

21. Coleridge, "To Nature" in Linzey and Regan, Song of Creation, ibid, p. 68.

22. George Herbert, "Providence" in The Works of George Herbert, ed. with comm. by F. E. Hutchinson (Oxford: The Clarendon Press, 1967) p. 117, and cited and discussed in the Patemoster, ibid, p. 8 f.

23. Philippians 2: 5-7(RSV). This Christological argument is developed at length in Andrew Linzey, "The Place of Animals in Creation - AChristian View" in Tom Regan (ed.), Animal Sacrifices: Religious Perspectives on the Use of Animals in Science (Philadelphia: Temple University Press, 1986), pp. 115/148.

24. Thomas Torrance, Divine and Contingent Order (Oxford: Oxford University Press, 1981), pp. 129/130 (my emphasis).

25. John Zizioulas, "Preserving God's Creation. Three Lectures on Theology and Ecology" in King's Theological Review, XII, 1, (Spring, 1989), p. 3.

26. Barth, Church Dogmatics, III/4, The Dactrine of Creation, edited by G. W. Bromiley and T. F. Torrance (Edinburgh: T. \& T. Clark, 1961), p. 355. In context, Barth is discussing the morality of killing animais for food. His conclusion is revealing. Meat eating can only be justified in the meantime between creation and consummation. Vegetarianism represents a "wanton anticipation of what is described by Is. 11 and Rom. 8 as existence in the new aeon for which we hope," pp. 355/6 n.

27. See, for example, Frances Young, The Use of Sacrificial Ideas in Greek Christian Writers from the New Testament to John Chrysostom, Patristic Monograph Series, no. 5 , (Philadelphia: The Philadelphia Patristic Foundation, 1979), pp. 54 ff.
28. H. H. Rowley goes as far as to suggest that "all the animal sacrifices of the Temple were abolished for the Church" and that in so doing it "repudiated a part of the inheritance of Judaism." The Biblical Doctrine of Election (London: Lutterworth Press, 1950), p. 163.

29. Romans 8: 19 - 22 (RSV).

30. Keith Ward, The Promise (London: SPCK, 1980), p. 2.

31. Nietzsche, Thoughts Out of Season, ET by Adrian Collins (Edinburgh: T. N. Foulis, 1909), p. 149. I am grateful to Ildi Clarke for this reference.

32. Nietzsche, ibid, p. 154.

33. St. Isaac the Syrian cited in Vladimir Lossky, The Mystical Theology of the Eastern Church, ET by the Fellowship of St Alban and St Sergius (Cambridge: James Clarke, 1973) p. 111; also cited and discussed in A. M. Allchin, The World is a Wedding: Explorations in Christian Spirituality (London: Darton, Longman and Todd, 1978)p. 85; also extract from Lossky in Linzey and Regan, Animals and Christianity, ibid, pp. 34/6.

34. Humphry Primath A Dissertation on the Duty of Mercy and the Sin of Cruelty to Brute Animals (Edinburgh: $T$. Constable, 1776) p. 288; also extract in Animals and Christianity, ibid, pp. 127/130.

35. Torrance drawing upon scientific models offers a most satisfying interpretation of natural evil, see, ibid, pp. 113/128.

36. Schweitzer, Civilization and Ethics, ET by C. T. Campion (London: Allen and Unwin, 1967), p. 221.

37. Zizioulas, ibid, p. 1.

38. Schweitzer, My Life andThought: An Autobiography ET by C. T. Campion (London: Allen and Unwin, 1933), pp. 279/80.

I am grateful to Dr Peter J. Wexler of the University of Essex, who kindly read an earlier draft of this paper and gave me the benefit of his comments. I am happy to acknowledge his help without thereby identifying him as the source of the views I express or the errors I commit. 